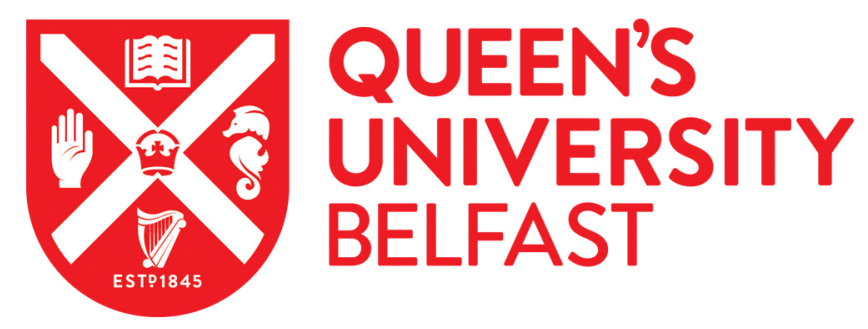

\title{
Understanding the purchase intentions for organic vegetables across EU: a proposal to extend the TPB model
}

Loera, B. L., Murphy, B., Fedi, A., Martini, M., Tecco, N., \& Dean, M. (2022). Understanding the purchase intentions for organic vegetables across EU: a proposal to extend the TPB model. British Food Journal. https://doi.org/10.1108/BFJ-08-2021-0875

Published in:

British Food Journal

Document Version:

Peer reviewed version

Queen's University Belfast - Research Portal:

Link to publication record in Queen's University Belfast Research Portal

Publisher rights

Copyright 2022 the authors.

This is an open access Creative Commons Attribution-NonCommercial License (https://creativecommons.org/licenses/by-nc/4.0/), which permits use, distribution and reproduction for non-commercial purposes, provided the author and source are cited.

\section{General rights}

Copyright for the publications made accessible via the Queen's University Belfast Research Portal is retained by the author(s) and / or other copyright owners and it is a condition of accessing these publications that users recognise and abide by the legal requirements associated with these rights.

\section{Take down policy}

The Research Portal is Queen's institutional repository that provides access to Queen's research output. Every effort has been made to ensure that content in the Research Portal does not infringe any person's rights, or applicable UK laws. If you discover content in the Research Portal that you believe breaches copyright or violates any law, please contact openaccess@qub.ac.uk. 


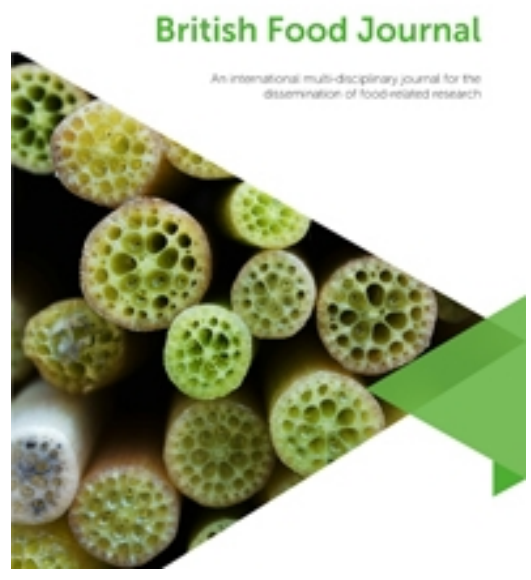

\section{Understanding the purchase intentions of organic vegetables across EU. A proposal to extend the TPB model}

\begin{tabular}{|r|l|}
\hline Journal: & British Food Journal \\
\hline Manuscript ID & BFJ-08-2021-0875.R1 \\
\hline Manuscript Type: & Research Paper \\
\hline Keywords: & Consumer Attitudes, Organic Food, Purchasing \\
\hline \multicolumn{2}{|l}{} \\
\hline
\end{tabular}

\section{SCHOLARONE} Manuscripts 


\title{
Understanding the purchase intentions of organic vegetables across EU.
}

\section{A proposal to extend the TPB model}

\begin{abstract}
Design/methodology/approach

The Theory of Planned Behaviour (TPB) is the most useful predictive model of purchase intentions, which can be viewed as the product of various psychological determinants. Previous works have proposed extensions of the TPB model to selectively include knowledge, trust or social norms, but an integrated proposal has not yet been formulated. Based on a survey in four European countries (Germany, Italy, Poland and the UK; N=1035), this study tests the process of organic vegetable purchase intention development using a structural equation model (SEM). This comprises part of the measurement of latent variables and part of the analysis of dependency relationships (MLR estimation method).

\section{Purpose}

The study aims to propose a systematic and innovative model of purchase intention development that integrates TPB with its main extensions and clarifies the logical status of the variables involved and the structure of the causal path.

\section{Findings}

The results show that purchase intention for organic vegetables is primarily dependent on positive moral attitude (PoMA) towards such consumption. The inclusion of PoMA reduces the effect of attitude toward buying organic vegetables, but the effects of social norms, past behaviour, and perceived behavioural control remain significant.

\section{Originality}


This study proposes an innovative model to explain purchase intention for organic vegetables that incorporates the key current extensions of the TPB model (knowledge, trust, and positive moral attitude) into an integrated causal pathway. Understanding the relationships between the antecedents of purchase intention provides relevant information on 'what' needs to be improved and 'where' interventions are needed to steer consumers towards organic food.

\section{Keywords}

TPB Model, SEM, Purchase intention, Positive moral attitude (PoMA), Organic vegetables 


\section{Understanding the purchase intentions of organic vegetables across EU.}

\section{A proposal to extend the TPB model}

\section{Conceptual framework and hypotheses}

Organic consumption has increased dramatically in recent decades. Consumption has grown rapidly in European countries, which represent the second largest market for organic food in the world after the USA (Monier-Dilhan \& Bergès, 2016; Willer et al., 2019). Although neither the growth nor the actual per capita consumption is the same in all countries, "the size of the organic market almost doubled in the decade from 2008 to 2017" (Willer et al., 2019, p. 239). In some countries, such as Germany or France, retail sales are particularly high, in others, such as Poland and the Eastern countries, they are increasing at a slower rate, and in still others, such as the United Kingdom after Brexit, they are declining due to political factors (Willer et al., 2019). Across Europe, consumption is higher than production, but in some countries, such as Italy, the number of processors has steadily increased (Willer et al., 2019). The most expanding sector is agricultural production; the total organic area in the EU grew by 4.3 million hectares between 2012 and 2019, an increase of almost half (45.9\%). Fresh vegetables are among the most important arable crops: in 2019, about one tenth (9.7\%) of the area used for fresh vegetable production in the EU was managed organically (Eurostat, 2021; Radulescu et al., 2021).

Understanding the factors underlying consumer purchasing behaviour is crucial to improve organic food consumption and, in particular, vegetable demand in both consolidated and new EU markets.

From a psychosocial perspective, purchase has several determinants, even though the act of buying a food product has been conceptualised mainly as a behavioural triggering of an 
intention (Saba and Messina, 2003; Thøgersen, 2009), which in turn can be considered as the product of several psychological components. This crucial assumption derives from the Theory of Planned Behaviour (TPB; Ajzen, 1991), one of the most widely used models to analyse the personal determinants of food consumption and organic food in particular (Aertsen et al., 2009; Dean et al., 2012; Scalco et al., 2017). The TPB model, originally developed by Ajzen (1991), is an evolution of the reasoned action model (Fishbein and Ajzen, 1975; Hagger, 2019) and assumes that behaviours are derived from behavioural intentions formed by attitudes, subjective norms, and perceived behavioural control (Ajzen and Madden, 1986), which in turn are based on beliefs. The TPB model is parsimonious and focuses primarily on the antecedents that its authors consider to be necessary and sufficiently logical causes of behavioural intentions (Ajzen, 1991). However, researchers have gradually experimented with other psychological traits that may be involved in the development of purchase intention for organic products and have proposed several extensions of the TPB model (e.g., Carfora et al., 2019).

\subsection{Extensions of the Theory of Planned Behaviour to explain organic food purchasing intention}

Arvola et al. (2008), Ajzen (2015), Menozzi et al. (2015), and Spence et al. (2018) have highlighted several dimensions that can be added to the classic determinants of intention, such as behavioural frequency, strength of habit, knowledge, and confidence. Some studies (Aertsens et al., 2011; Marques Vieira et al., 2013) have extended the traditional TPB model by adding objective and subjective knowledge to the possible determinants of organic food purchasing behaviour. Pieniak et al. (2010) specifically analysed the role of objective and subjective knowledge in determining attitudes toward the purchase and 
consumption of organic vegetables. Their results show a significant difference between objective knowledge (actual level of knowledge) and subjective knowledge (consumers' "perception of what or how much they know"; p. 582). Subjective knowledge had a stronger and more direct influence on attitudes toward buying organic vegetables than objective knowledge because subjective knowledge "includes an element of perceived certainty or uncertainty" (p. 586), even though uncertainty was not explicitly measured.

Bai et al. (2019) recently proposed an extended TPB model to explain organic food purchasing in the emerging Chinese market, and considered beliefs toward organic food, subjective norms, and perceived product trustworthiness as antecedents, in addition to "classic" attitudes toward organic food and perceived behavioural control. Beliefs were analysed as meaningful predictors of attitudes towards purchasing behaviour, following Fishbein and Ajzen's (2009) expectancy-value theory. Beliefs generally related to organic food, namely that it is healthier and tastier than conventional food and environmentally friendly, contribute to influence purchase intention for organic food (Saba and Messina, 2003; Aertsen et al., 2009). Subjective norms can be defined as perceived social pressure to engage (or not) in a behaviour and are considered as antecedents of intention (Ajzen and Madden, 1986). In the case of food choices, the desire to consider "significant others" (family, friends, relatives, work colleagues, and other reference groups; Scalco et al., 2017) when purchasing and eating organic food correlated with the intention to purchase sustainable products (Dean et al., 2008; Aertsen et al., 2009). De Kervenoael et al. (2020) considered subjective norms as a function of (un)perceived barriers to purchase: they facilitate the intention to purchase healthy and sustainable products.

Perceived trustworthiness has been considered an antecedent of purchase intention (Nuttavuthisit and Thogersen, 2017). Bai et al. (2019) indicated a relationship between 
purchase intention, beliefs about purchase, and perceived trustworthiness. Several recent studies (Giampietri et al., 2018; Spence et al., 2018) included consumer trust among the antecedents of food purchase intention and behaviour, especially for organic food (Carfora et al., 2019). Consumer trust is crucial in food markets (Benson et al., 2020), but especially for organic food. Indeed, organic is a trust attribute (Perrini et al., 2010), because consumers have no clues about authenticity either before (e.g., appearance of the product) or after (e.g., taste) purchase. Thus, they have to trust that the actors in the supply chain have complied with the criteria of organic production. If consumers do not trust organic food and/or the organic guarantee system, they are unlikely to buy it. Consumer trust has only been considered as a possible prerequisite for purchase intention and research has not explored the role of trust (or multiple dimensions of trust; Pivato et al., 2008; Hobb and Goddard, 2015; Carfora et al., 2019; Benson et al., 2020) within the components of the TPB model. An exception is the model proposed by Nuttavuthisit and Thogersen (2017), which includes trust in the classic version of TPB, both as a direct antecedent of purchase behaviour and as an antecedent of beliefs. Thus, lack of consumer trust dampens the development of green product markets in at least two ways: indirectly, through less favourable beliefs that lead to less favourable attitudes and intentions, and directly, by reducing consumers' propensity to purchase the product even if they intend to do so. In addition, Sultan et al. (2020) examined trust as a moderator between environmental purchase intention and behaviour, although they did not consider the role of trust in the development of purchase intention. Based on the TPB framework and considering the integrations just discussed, an initial hypothesis was formulated:

Hp1: The development of purchase intention is a process based on past behaviour and psychological background variables, involving knowledge, trust and personal norms. 
Several works (Arvola et al. 2008; Dowd and Burke, 2013; Saleki et al., 2019; Liu et al., 2020; Lafontaine et al., 2021) have highlighted the possibility of considering moral and ethical dimensions when analysing the determinants of an ethically connoted behaviour such as organic purchasing. In this direction, Dowd and Burke (2013) proposed another TPB extension to compensate for the absence of the moral dimension (Arvola et al., 2008) among the determinants of purchase intention. They added the positive moral attitude, which occurs when individuals believe that their actions can fulfil their moral values and have positive consequences (Arvola et al., 2008; Olsen, Sijtsema, and Hall, 2010; Dowd and Burke, 2013). According to both Arvola et al. (2008) and Dowd and Burke (2013), moral and ethical dimensions cannot be disregarded when analysing the antecedents of intention to purchase organic food, as they are often guided by "the anticipated positive feelings of doing the right thing" (Dowd and Burke, 2013, p. 138), as they also play a role in the choice of food from sustainable production. Therefore, we can hypothesise the following:

Hp2: The normative component of the process underlying the intention to buy organic food should be measured primarily by considering the ethical/moral components that characterise and value the choice of this particular type of product.

\subsection{Purchase intention: the logical status of predictors.}

TPB expansion in the context of organic food can be reduced to three prominent macroconstructs: subjective/objective knowledge about organic food, trust in organic (i.e. in producers, retailers, certifications, etc.) and the (positive) moral connotation of buying organic food. Typically, these constructs are added to the model as observed variables measured with specific scales, as are the traditional antecedents in the TPB model. From a psychometric perspective, the TPB and its extensions are conceptualised and estimated as a 
path model in which the newest predictors are treated as the traditional exogenous variables or as exogenous mediators/moderators of the path originally specified by behavioural intention development theory. Accordingly, organic consumer trust, subjective and/or objective knowledge about organic products, and positive moral attitudes toward organic purchasing, similar to attitudes toward the act of purchasing, subjective norms, and perceived behavioural control, are generally considered as direct determinants of purchase intention or as mediating variables in the formation of the intention. However, we can hypothesise that these added constructs might have a specific logical status that differs from the traditional antecedents of TPB: they might contribute to the development of the behavioural intention by influencing (directly and indirectly) each component of the original model.

Trust in certified food and the organic chain, as well as (objective and subjective) knowledge about organic food and (subjective and perceived moral) norms for buying organic food, could be conceived as unobserved background variables, i.e. latent psychological constructs that determine consumers' attachment to organic food. They arise from previous experiences related to the purchase of organic food and could play the role of a cognitive framework that influences (directly or indirectly) the classical antecedents of behavioural intention by contributing to subjective norms, perceived behavioural control and the belief system underlying the attitude. Background psychological variables (i.e., trust, knowledge, and norms) may influence attitudes toward organic food purchase because they summarise various prior cognitions that contribute to the development of the belief system regarding organic food consumption. Moreover, these latent variables, together with prior behaviours, might influence perceptions of the control one can exert when making a purchase: just as prior experiences can promote internal control by reinforcing self-efficacy and acquired skills, knowledge of the organic chain and systemic trust (in producers, retailers, certification 
processes, and products) might narrow the consumer's scope of action into less risky boundaries. The perception of acting from a known and reassuring position, with clear horizons and trusted actors, could improve the level of perceived control over decisionmaking and behavioural space (Notani, 2008). Perceived control over purchasing behaviour is indeed usually expressed through the availability of goods or the affordability of the premium price of organic products (e.g. Nuttavuthisit and Thøgersen, 2017), but may also be related to trust in the product (Aertsens et al., 2009): lack of trust may represent a perceived lack of control over the product being purchased. The normative side of the psychological background variables could also have an impact on moral attitudes towards the purchase of organic food, as this type of consumption is considered socially desirable, i.e. valued and shared as good. We can expect that the positive moral attitude partly results from subjective and social norms and partly involves the moral implication of the belief system about organic. This has already been suggested by Ajzen and Fishbein (1980) and Arvola et al. (2008): if people have a positive attitude toward a behaviour (considered ethically right) and at the same time believe that their significant others think they should do it, they are likely to perform that behaviour (Kokkinaki, 2009). In addition, positive moral attitudes could act as a driver for purchase intention, as it represents both self-serving gratification and a motivation to contribute to the sustainability and safety of the food system by supporting the organic chain.

Finally, some authors such as Arvola et al. (2008) have theoretically reviewed various possible extensions of the TPB model, but to our knowledge no work has systematized these different components into an integrated model that can clarify the logical status of the different antecedents of purchase intention for organic food. The aim of the present work is therefore to fill this gap. We intend to develop an extended version of the TPB model that integrates 
the main previous proposals, offer a new integrated model and test it empirically. We focus on organic vegetables, which are a particularly representative category of organic products (Christensen et al., 2020), especially in the European market, where the largest increase in organic production in terms of cultivated area concerns vegetables and oilseeds, showing that organic farmers are meeting the increasing market demand (Willer et al., 2019).

The model proposed in this paper does not simply add some more antecedents of purchase intention for organic vegetables to attitudes, subjective norms, and perceived behavioural control. It therefore integrates the newest constructs into the model of planned behaviour and arranges the constructs in a logical order by clarifying at which point in the predictive path they intervene through the following four hypotheses:

Hp3: Attitude develops from a system of personal beliefs regarding the purchase of organic vegetables, which in turn is based on knowledge about organic products, trust in the products and the supply chain, and social and individual norms regarding this behaviour.

Hp4: Perceived behavioural control is influenced by past behaviour, knowledge of organic produce and consumer trust in organic produce, as these are three different sources of assurance and certainty that reduce the perceived risks associated with buying organic vegetables.

Hp5: Attitude, positive moral attitude, and perceived behavioural control, along with past behaviour, are the three direct determinants of intention.

Hp6: Past behaviours and background psychological variables (i.e., norms, knowledge, and trust) directly affect the endogenous variables composing the process of intention development and also exert indirect effects on purchase intention. 
The entire set of hypotheses can be tested using the structural equation model (SEM) shown in the following figure.

-Please insert Figure 1-

\section{Methodology}

In order to propose a more integrated model to explain purchase intention for organic vegetables, we primarily examined previous work that has used the TPB model to clarify purchase intention for organic vegetables and its extensions; among others, to guide the definition of the research design: Ajzen (2006), Van Rijswijk and Frewer (2008), Dean et al. (2008), Aertsen et al. (2009), Arvola et al. (2008), Pieniak et al. (2010), Aertsens et al. (2011), Dean et al. (2012), Dowd and Burke (2013), Marques Vieira et al. (2013), Menozzi et al., (2015); Teng and Lu (2016), Yadav and Pathak (2016), Nuttavuthisit and Thøgersen (2017), Scalco et al. (2017), Giampietri et al. (2018), Spence et al. (2018), Benson et al. (2020), De Kervenoaele et al. (2020). On the basis of these contributions, we have speculated on a more comprehensive model that follows the "Discovery by Integrating Multiple Past Studies" process proposed by McGuire (1997, p. 23). In addition, because we wanted to clarify the logical status of the antecedents of purchase intention, we defined the various hypotheses we wanted to test empirically using a structural equation model, in accordance with the "heuristic requiring complex conceptual analysis" described by McGuire (1997, p. 16). Considering previous research designs on this topic and existing instruments to measure the dimensions involved, we developed an online questionnaire for organic consumers. 


\subsection{Design}

In order to get an overview of the whole EU market, four countries (Germany, Italy, Poland and the UK) were selected on the basis of their emblematic organic history: from the established Italian market for organic food to the scepticism of the well-developed German and UK markets and the rapidly developing Polish market. Previous research on trust has found that the UK and Germany have low overall trust and low confidence in food (Murphy et al., 2020). Italy has a reputation for having a strong organic market with enthusiastic consumers of organic and local produce (Janssen and Hamm, 2014). Poland is a rapidly developing organic food market with a value that has grown from around $€ 1.5$ million in 2004 to over $€ 235$ million in 2017 (Pawlewicz et al., 2020).

Furthermore, looking at the results of FiBL statistics (based on national data sources, data from certifiers and Eurostat; Willer, 2020), Italy was the country with the highest prevalence of organic producers in 2019 ( $N=70561)$, Germany was the more extended market with a turnover of $€ 11970$ million in organic retail sales, while Poland was the faster growing market with an increase to $€ 314$ million in 2019 (a sales change of $+528 \%$ in ten years, i.e. since 2009 , and a change of $+33 \%$ compared to 2017 ). The UK was the only country where the trend over the last ten years was in the opposite direction: from 2009 to 2019, the share of organic land in total agricultural land halved, and the number of producers fell to 3581 (a change of over $30.5 \%)$.

The data collection was entrusted to a research agency (Dynata), which was able to recruit representative samples of consumers in each country and conduct the online survey in different languages, with the formulation of the questionnaire and its cultural adaptation carried out by the research group itself. At the end of 2019, respondents from the four participating countries answered questions about organic vegetables. To avoid bias, 
respondents under the age of 18 or those working in (or living in a household with) food safety, food processing or manufacturing, or farming, growing, wholesaling or retailing food or beverages were excluded. To ensure sufficient variance for the relevant dependent and independent variables, participants were selected using quota sampling to ensure that: (a) each respondent had some responsibility for purchasing food in their household; (b) at least $60 \%$ of respondents purchased organic food at least "several times a month"; and (c) the proportion of respondents from upper and lower social class households was approximately equal. The questionnaire was approved by the XXX -Blinded for submission University School of Biological Sciences Research Ethics Committee (Approval N. 09/19/ XXX -Blinded for submission; September 2019).

\subsection{Participants}

A total of 1035 people participated, roughly representative in terms of gender, age and region. The majority of them were female $(52.5 \%)$, had a mean age of 47.68 years $(S D=16.47$, range $=18$ to 85 ) and were evenly distributed among the 4 countries (UK $=254$; Germany $=$ $258 ;$ Italy $=258$, Poland $=265$ )

Despite some demographic differences in the sample (see Table 1), respondents were mostly well educated, had no children under 16 in the household, were married or living with their partner, and were working full-time or retired. However, due to the topic (organic food) this was to be expected.

-Please insert Table 1-

Table 1. Socio-demographic characteristics of the respondents 


\subsection{Survey instrument}

The questionnaire was tested with individuals of different ages, education levels, and genders to assess comprehension and function (online delivery, question order, filters, instructions, and duration). The initial quota sampling questions captured respondents' organic food purchasing habits and basic demographic data (age, gender).

The final questionnaire consisted of socio-demographic information (marital status, number of children in the household, and occupational status) and 5 content sections: traditional planned behaviour variables, strength of organic habit, knowledge of organic, positive moral attitude toward buying organic food, and consumer trust in organic food. The sections in detail were the following.

Theory of Planned Behaviour (TPB): TPB items were defined based on guidelines proposed by Ajzen (1991; 2006) and research on similar topics (Dean et al., 2012; Menozzi et al., 2015; Spence et al., 2018; Van Rijswijk and Frewer, 2008), as well as an unpublished focus group study conducted by the authors $(n=34)$. The measurements included items inherent to: perceived social norms; subjective norms; perceived behavioural control; behavioural beliefs; attitude towards buying organic vegetables; purchase intention. Habit strength was measured using a single item on past behaviour adapted from Spence et al. (2018).

Knowledge and Uncertainty: consumers' objective knowledge was assessed using validated items from Aertsens et al. (2011). Respondents' subjective knowledge was measured using validated items from Aertsens et al. (2011) and Marques Vieira et al. (2013). Respondents' uncertainty and confidence in knowledge about organic vegetables and product information was assessed using six items from Teng and Lu (2016).

Positive moral attitude (PoMA) towards buying organic food was measured using validated items from Dean et al. (2012) adapted for organic vegetables. 
Consumer Trust: four trust constructs were assessed using the validated Trust toolkit (Benson et al., 2020). Specific organizations and product were used for three constructs: Trust in the organization (European Food Safety Authority (EFSA)); Trust in the product (organic vegetables); Trust in the food chain (national organic certification body). The national organic certification body was adapted to the country of the respondent (UK \{Soil association\}, Germany \{Bundesverband der Oeko-Kontrollstellen\}, Italy \{Mipaaft $\}$ and Poland $\{$ Ekoland\}). Specifically, the following types of consumer trust were examined: Interpersonal trust, i.e. how trustworthy are people in general; Organizational trust, i.e. how much a person trusts organizations outside the food chain; Food chain trust, i.e. how much a person trusts the actors and/or organizations involved in food production; Product trust, i.e. how much a person trusts a particular product (in this case organic vegetables).

Further details on the survey instruments can be found in Table 2 .

- Please insert Table 2 -

Table 2. Constructs and items: examples, number and response scale of the items included in the survey instrument

\subsection{Statistical Analysis}

The internal consistency and homogeneity of each scale included in the questionnaire was assessed using the Cronbach's $\alpha$-coefficient and item analysis (item-total correlation, item Rsquared). In addition, composite reliability (CR) and average variance extracted (AVE) were also examined considering a unidimensional structure (principal components) for each scale (McKenzie et al., 2011). Therefore, scale scores were determined by the mean of each item 
rather than the sums in order to maintain the same range of item scales and reduce measurement error.

Bivariate correlations between scale scores were examined to test whether the measured variables formed an expected network of relationships consistent with the TPB and previous research findings.

In order to test the hypothesis about the process of organic food purchase intention development, a structural equation model (SEM) was specified. This includes a part of latent variable measurement and a part of dependence relationship analysis (MLR estimation method).

The usual fit indexes were used to evaluate and compare the models: Comparative Fit Index (CFI) (Bentler, 1990), the root-mean square error of approximation (RMSEA) (Browne and Cudeck, 1993), and the standardized root-mean squared residual (SRMR) (Jöreskog and Sörbom, 1981; Bentler, 1995).

CFI values range between .0 and 1.0 (Bentler, 1990), with values closer to 1.0 indicating good fit. A cut-off criterion of $\mathrm{CFI} \geq .90$ is considered sufficient, even if a value $\mathrm{CFI} \geq .95$ is presently recognized as indicative strong of good fit (Hu and Bentler, 1999). Recommendations for RMSEA cut-off points have been changed several times, but recently there is a general consensus proposing a cut-off value close to .06 (Hu and Bentler, 1999) or .07 (Steiger, 2007), with a confidence interval where the lower limit is close to 0 while the upper limit should be less than .08.

Values for the SRMR range from zero to 1.0 with well-fitting models obtaining values less than .05 (Byrne, 1998; Diamantopoulos and Siguaw, 2000), however values as high as .08 are deemed acceptable (Hu and Bentler, 1999). 
The coefficients of indirect effects were estimated using bootstrap method. Statistical analyses were performed using the IBM SPSS software, version 26, and MPlus, version 8.4.

\section{Results}

\subsection{Scales reliability, scores description and correlations}

The reliability of the scales was considerable (Table 3 , on the diagonal): the internal consistency of the items was good and Cronbach's alpha ranged from .748 to .986 , with the exception of the two subsets of items measuring perceived behavioural control (PeBC .648), which consisted of only three items, and objective knowledge (ObK .607), which was measured by dichotomous items. The same remarkable results on the reliability of the scales were obtained from the values of AVE and CR: considering each scale as unidimensional, the percentage of observed variance attributable to its latent factor was on the average always above .5 , and the composite reliability value ranged from .814 to .987 .

The descriptive results are also shown in Table 3. Each variable composing the TPB and its extensions was assessed by calculating the mean of the respective items, except for past behaviour (single item) (Table 4). For most variables, scores ranged from 1 to 7 , with a high score indicating a high or positive level of individual positioning on the measured constructs, while past behaviour and objective knowledge ranged from 1 to 8 and 1 to 4 , respectively, consistent with the original formulation (Spence et al., 2018; Aertsens et al., 2011).

Respondents reported buying organic vegetables fairly frequently (Past) and intended to buy organic vegetables in the future (PInt). Organic vegetables were perceived by consumers as available and easy to buy, resulting in a moderately high mean score of perceived behavioural control (PeBC). 
The expressed attitude towards buying organic food was positive (Att) among all the respondents and accordingly the score of beliefs regarding buying organic vegetables was also high (Bel). The beliefs were similar among all the respondents; they believed that organic vegetables were healthier, more enjoyable and sustainable, but also more expensive. Perceived social norms and subjective norms scored high: significant others and social approval seemed to be important to respondents (PeSN), although less so than the positive evaluation of the moral implications of buying organic vegetables: the mean score of positive moral attitude (PoMA) was 5.

Participants exhibited a reasonable level of objective knowledge about organic vegetables (ObK), were confident they had a good knowledge of organic products (SbK) and their level of uncertainty was low (Unc).

Finally, respondents reported a favourable trust profile, both systemic, interpersonal (IntT) and organisational (OrgT), and specific to the organic chain (ChT) and products (ProT) relevant to the vegetable sector.

- Please insert Table 3 -

Table 3. Scores description (M, SD), Cronbach's alpha (on the principal diagonal), AVE and bivariate correlations

Intention to buy organic vegetables was significantly correlated with all other variables, especially ( $r \geq .50$ ) with those corresponding to the traditional TPB model, i.e., attitude toward buying organic vegetables, agreement with beliefs about buying organic vegetables, and subjective norms. However, PoMA was the variable most strongly associated with intention to purchase organic vegetables: respondents with more positive moral attitudes and (positive) cognitive and emotional attitudes towards buying organic vegetables showed 
higher intentions to buy organic products in the future. Similarly, those who shared the belief that organic is healthier, tastier, and more sustainable, and who reported higher subjective norms due to the influence of significant others, expressed higher intentions to purchase organic vegetables. Although prior behaviour was only measured by a single item, it showed a significant relationship with purchase intention for organic vegetables, while the coefficient of perceived control over actual purchase appeared lower, suggesting that this TPB variable may be less crucial than others in understanding purchase intention for organic vegetables. Strong correlations $(r \geq .30)$ were found between purchase intention and the different trust orientations, with the strongest relationship in trusting organizations, including food certification bodies. Less strong, although significant and noteworthy, were the correlations between purchase intention and knowledge, although the relationship with objective knowledge was weak and smaller than that with subjective knowledge. Significant and inverse, as expected, was the correlation between purchase intention and uncertainty. Due to their partially overlapping semantics, the correlations between some construct measures were strong, as in the case of PeSN and SbN or Att and PoMA.

\subsection{Structural equation models}

Standard regression models commonly used to estimate TPB consider all predictors at the same logical level. In contrast, the analyses of SEM assume a more complex causal chain, with a logical-theoretical ordering between the determinants of purchase intention and the presence of latent variables.

The specification of SEM followed the six study hypotheses, so the exhaustive model included the:

- measurement of three latent variables (labelled Know, Trust and Norms); 
- direct effects of the latent variables on the beliefs system intermediating Att and PoMA;

- direct effects of the latent variables on Att, PoMA and PeBC;

- direct effect of Att, PoMA, PeBC and Past on the purchase intention;

- indirect effect of the latent variables on the purchase intention.

The full model yielded a poor fit (CFI =.881, RMSEA=.093, C.I. .087-.099, SRMR=.106), indicating some misspecification: the measurement portion of the SEM was adequate, although the formative role of Past did not emerge regarding Trust (Hp1 partially confirmed), and some direct and indirect paths were not significant or occurred although they were not predicted.

As expected, the effects of the latent exogenous variables on the observed endogenous variables were selective: Trust and Know affected PeBC, while Norms affected PoMA and the three together exerted an influence on the belief system (Bel) regarding organic vegetables (Hp2 and Hp3 confirmed). PeBC did not depend on Past, even indirectly (Hp4 partially confirmed). Purchase intention for organic vegetables was directly influenced by Att, PoMA, and $\mathrm{PeBC}$, but the modification indices suggest the addition of a direct and unanticipated effect of Past (Hp5 partially confirmed). Finally, the only significant and remarkably consistent indirect effect is the one related to beliefs: no other indirect effect was large enough to be considered even if significant (Hp6 partially confirmed).

In view of these results, the specification of SEM was improved and the final model achieved a sufficiently good fit: $\mathrm{CFI}=.912, \mathrm{RMSEA}=.077$ (C.I. .071-.078), SRMR $=.064$. The proportion of variance explained for purchase intention was .576 , and the $R^{2}$ for the other endogenous variables were adequate $\left(R^{2} A t t=.384, R 2 P o M A=.633, R^{2} B e l=.381\right)$, except for PeBC, which accounted for $15.5 \%$ of its observed variance. The indirect effect of Bel on intention was significant ( $p<.001)$ and appreciable: a total of .389, of which .255 via PoMA and .134 via Att. 
The standardized estimates are shown in Figure 2. All the standardized coefficients showing the measurement of the latent variables and the coefficients of the causal path were statistically significant $(p<.001)$.

- Please insert Figure 2 -

Figure 2 shows the strong relationship between attitudes towards buying organic vegetables and the positive moral implication of choosing organic food instead of conventional food, which remains even after accounting for Bel and Norms dependence $(r=.263)$. Regarding the measurement part of the model, it is observed that the three latent variables are correlated with each other and the strongest relationship is between Trust and Norms $(r=.660)$. The contribution of objective knowledge to the latent background variable resuming acquired knowledge about organic was weak (loading, $\lambda=.253$ ).

\section{Discussion}

The aim of our work was to propose a more comprehensive and integrated version of the TPB model to explain the purchase intention for organic vegetables. In doing so, we incorporated the most important previous extensions of this model and clearly defined the logical status of the considered constructs.

A more significant extension of the model was achieved by including positive moral attitude, which, to our knowledge, has never been considered in studies explaining organic food purchase using extended TPB models (Aertsen et al., 2009; Dean et al., 2012; Nuttavuthisit and Thøgersen, 2017; Scalco et al., 2017; Carfora et al., 2019). In our study, positive moral attitudes emerged as a fundamental factor supporting the purchase of organic vegetables. 
The value connotation of buying organic, perceived as good and fair, was the factor that contributed more than others to this choice. Moreover, the inclusion of this new variable reduced the effect of attitude, while the other effects related to social norms, past behaviour, and perception of control over purchasing behaviour remained unchanged.

The addition of knowledge variables (objective and subjective) or trust variables did little to explain purchase intention, i.e., it does not appear to be a useful extension of the TPB model: the increase in complexity was accompanied by an irrelevant increase in explanatory power. Moreover, only subjective knowledge and generalized institutional trust had significant effects, while the effects of the more specific variables, such as supply chain trust and product trust, were not significant.

The shift to a more sophisticated data analysis model that postulates a causal path rather than simultaneity of all explanatory variables proved useful for a deeper understanding of the evolution of purchase intention for organic vegetables. As hypothesized, variables that might appear redundant (statistically and substantively) in the regression models were able to contribute to the explanation of purchase intention in the path analysis, i.e., when specified as background variables that precede and influence the traditional TPB predictors. Path analysis has shown that four main factors are responsible for buying behaviour, in ascending order of influence:

- $\quad$ perceived control over the buying behaviour, i.e., its feasibility;

- past behaviour, which facilitates the repetition of organic purchase both directly and indirectly by providing the experiential information that contributes to the development of normative beliefs and knowledge about organic vegetables; 
- attitudes towards buying organic vegetables, i.e. the positive evaluation of the consequences of buying a product that is considered purer, healthier and more sustainable;

- moral attitude towards the purchase of organic vegetables.

As expected, this last factor was the most important in determining intention to purchase organic vegetables. For consumers, buying organic vegetables has value, not only because of the health benefits attributed to eating the product, but also because it represents a value in itself, a choice that is seen as more environmentally friendly and therefore more sustainable. From the consumer's perspective, it can also be argued that the positive moral connotation of buying organic can also be experienced as attributing positive qualities to oneself: making better choices for health and the environment contributes to a positive self-perception, which is close to the concept of "self-identification with 'green' issues" already introduced by Dean et al. (2012, p. 673) as a determinant of attitudes towards buying organic food. This interpretation is also supported by the fact that positive moral attitudes are in turn influenced by beliefs regarding the qualities of organic vegetables and, to a considerable extent, by normative beliefs prescribing 'having to be'. The perception of living in a social context in which the organic supply chain is to be preferred, as well as the awareness that one's own family members and reference groups approve of the decision for organic, favours the valorisation of organic purchasing behaviour and thus perhaps also the self-representation as a careful and conscious citizen.

The normative system that results from subjective norms and perceptions of social norms is one of the three latent psychological variables that we have adopted as background variables and that have been shown to form the basis for the process of intention formation. Of the other two psychological background variables, one represents a genuine cognitive framework 
based on knowledge of the organic vegetable supply chain. The other represents a general orientation consisting of systemic trust in which it is possible to set different behaviours, not only purchasing behaviour. As hypothesized, both contribute to the development of the belief system regarding the environmental supply chain and define the scenario in which the purchase decision is made: prior knowledge and trustworthy 'investments' increase the perception of control over the decision to buy and consume organic vegetables.

\section{Conclusion}

Understanding which factors influence consumer choice of organic vegetables is useful in supporting a healthier and more sustainable dietary style that benefits consumers themselves and is an essential element in the development of the organic supply chain. As far as we know, there has been no previous work that summarised and empirically tested the various possible extensions of the TPB model. The results of this study contribute to this progress by indicating which variables are best associated with the development of purchase intention directed towards organic vegetables and the process leading to the formation of these decisions. Knowledge about the network of relationships between the predictors of organic vegetable purchase offers the various actors in the organic supply chain not only information about "what" they should do, but also "when" they should intervene, i.e. at what point in the process underlying purchase intention it might be appropriate to act. For example, which communication strategy should be developed to give consumers more guarantees that the organic vegetables they buy have the expected characteristics? Is it better to act on labels or on consumer confidence in certification bodies and producers?

The present results have limitations due to the nature of the study itself, as a causal model is assumed even though the data represent only a cross-section. Furthermore, due to the 
number of participants, the model was only estimated for the whole sample and it was not possible to replicate the analysis by country. However, it would be useful to test whether it remains valid in different national contexts with different food cultures and organic purchasing habits. In addition, organic vegetables may be too large a category and future studies should focus more on specific vegetables. The model should also be tested on other samples to see if the process of purchase intention formation postulated in the study is valid for other products in the organic sector, such as meat.

Despite these limitations, the specified path analysis model was able to produce some results that are useful in clarifying the relationships among factors that favour the purchase decision for organic vegetables. The present extension of the TPB model to include the three latent factors of trust, knowledge and norms, together with the analyses of their effects on positive moral attitudes and on the traditional TPB predictors, resulted in a more integrated framework for understanding purchase intentions for organic vegetables. This improvement opens the way for further research developments. In the first instance, it could be extended to other cultural contexts, such as Asian, African or American consumers. There also seems to be an urgent need to analyse purchase intention for organic food after the Covid-19: the pandemic could indeed reinforce this behavioural orientation by increasing its health and environmental value (Liu et al., 2021; Smiglak-Krajewska and Wojciechowska-Solis, 2021); but the pandemic crisis could also reinforce the barriers (e.g., economic or trust-related) that hinder the diffusion of this behaviour. The proposed model could also be tested for intentions to purchase different types of products, such as fair trade or environmentally friendly nonfood products, which are also influenced by moral dimensions (e.g. Ladhari and Tchetgna, 2015; Jacobs et al., 2018). Moreover, investigating the relationships between the considered 
dimensions and the final organic food purchase behaviour could be a further improvement of this proposed integrated model. 


\section{References}

Aertsens, J., Mondelaers, K., Verbeke, W., Buysse, J., and Van Huylenbroeck, G. (2011), 'The influence of subjective and objective knowledge on attitude, motivations and consumption of organic food', British Food Journal, 113(11), 13531378. https://doi.org/10.1108/00070701111179988

Aertsen, J., Verbeke, W., Mondelaers, K., and Van Huylenbroeck, G. (2009), 'Personal determinants of organic food consumption: A review', British food Journal, 111(19), 11401167. https://doi.org/10.1108/00070700910992961

Ajzen, I. (1991), 'The theory of planned behaviour', Organizational Behaviour and Decision Processes, 50, 179-211. http://dx.doi.org/10.1016/0749-5978(91)90020-T

Ajzen, I. (2006), Constructing a TpB questionnaire: conceptual and methodological considerations. Retrieved on the 19th of June 2021 from http://people.umass.edu/aizen/tpb.html.

Ajzen, I. (2015), 'Consumer attitudes and behaviour: the theory of planned behaviour applied to food consumption decisions', Rivista di Economia Agraria, 2, 121-138. https://doi.org/10.13128/REA-18003.

Ajzen, I., and Fishbein, M. (1980), Understanding attitudes and predicting social behaviour. Englewood Cliffs, NJ: Prentice Hall.

Ajzen, I., and Madden, T. J. (1986), 'Prediction of goal-directed behaviour: Attitudes, intentions, and perceived behavioural control', Journal of Experimental Social Psychology, 22, 453-474. http://dx.doi.org/10.1016/0022-1031(86)90045-4

Arvola, A., Vassallo, M., Dean, M., Lampila, P., Saba, A., Lähteenmäki, L., et al. (2008), 'Predicting intentions to purchase organic food: The role of affective and moral attitudes in 
the theory of planned behaviour', Appetite, 50, 443-454. https://doi.org/10.1016/j.appet.2007.09.010

Bai, L., Wang, M., and Gong, S. (2019), 'Understanding the Antecedents of Organic Food Purchases: The Important Roles of Beliefs, Subjective Norms, and Identity Expressiveness', Sustainability, 11, 3045. https://doi.org/10.3390/su11113045

Benson, T., Lavelle, F., Spence, S., Elliott, C. T., and Dean, M. (2020), 'The development and validation of a toolkit to measure consumer trust in food', Food Control, 110, 106988. https://doi.org/10.1016/j.foodcont.2019.106988

Bentler, P. M. (1990), 'Comparative fit indices in structural models', Psychological Bulletin, $107,238-246$.

Bentler, P. M. (1995), EQS Structural Equations Program Manual. Encino, CA: Multivariate Software.

Browne, M. W., and Cudeck, R. (1993), 'Alternative ways of assessing model fit'. In K. A. Bollen and J. S. Long (Eds.), Testing structural equation models (pp. 136-162). Newbury Park, CA: Sage.

Byrne, B. (1998), Structural Equation Modeling With Lisrel, Prelis, and Simplis: Basic Concepts, Applications, and Programming. Mahwah, New Jersey: Lawrence Erlbaum Associates Publishers.

Carfora, V., Cavallo, C., Caso, D., Del Giudice, T., De Devitiis, B., Viscecchia, R., Nardone, G., and Cicia, G. (2019), 'Explaining consumer purchase behaviour for organic milk: Including trust and green self-identity within the theory of planned behaviour', Food Quality and Preference, 76, 1-9. https://doi.org/10.1016/j.foodqual.2019.03.006 
Christensen, T., Denver, S., and Bøye Olsen, S. (2020) 'Consumer preferences for organic food and for the shares of meat and vegetables in an everyday meal', Journal of International Food \& Agribusiness Marketing, 32(3), 234-246. https://doi.org/10.1080/08974438.2019.1599758 Dean, M., Raats, M. M., and Shepherd, R. (2008), 'Moral concerns and consumer choice of fresh and processed organic foods', Journal of Applied Social Psychology, 38(8), 2088-107. https://doi.org/10.1111/j.1559-1816.2008.00382.x

Dean, M., Raats, M. M., and Shepherd, R. (2012), 'The Role of Self-Identity, Past Behaviour, and Their Interaction in Predicting Intention to Purchase Fresh and Processed Organic Food', Journal of Applied Social Psychology, 42(3), 669-688. https://doi.org/10.1111/j.15591816.2011.00796.x

De Kervenoael, R., Schwob, A., Hasan, R., and Ting, Y. S. (2020), 'Consumers' perceived value of healthier eating: A SEM analysis of the internalisation of dietary norms considering perceived usefulness, subjective norms, and intrinsic motivations in Singapore', Journal of Consumer Behaviour, 20(3), 550-563. https://doi.org/10.1002/cb.1884

Diamantopoulos, A., Siguaw, J. A., and Siguaw, J. A. (2000), Introducing LISREL A Guide for the Uninitiated. Sage Publications, London.

Dowd, K., and Burke, K. J. (2013), 'The influence of ethical values and food choice motivations on intentions to purchase sustainably sourced foods', Appetite, 69(1), 137-144. https://doi.org/10.1016/j.appet.2013.05.024

Fishbein, M., and Ajzen, I. (1975), Belief, Attitude, Intention, and Behaviour: An Introduction to Theory and Research. Reading, MA: Addison-Wesley.

Fishbein, M., and Ajzen, I. (2009), Predicting and Changing Behaviour: The Reasoned Action Approach. New York, NY, USA: Psychology Press. 
Giampietri, E., Verneau, F., Del Giudice, T., Carfora, V., and Finco, A. (2018), 'A Theory of Planned behaviour perspective for investigating the role of trust in consumer purchasing decision related to short food supply chains', Food Quality and Preference, 64, 160-166. https://doi.org/10.1016/j.foodqual.2017.09.012

Hagger, M. S. (2019), 'The reasoned action approach and the theories of reasoned action and planned behaviour'. In D. S. Dunn (Ed.), Oxford Bibliographies in Psychology. New York, NY: Oxford University Press.

Hobbs, J. E., and Goddard, E. (2015), 'Consumers and trust'. Food Policy, 52(C), 71-74. https://doi.org/10.1016/j.foodpol.2014.10.017

Hu, L. T., and Bentler, P. M. (1999), 'Cutoff Criteria for Fit Indexes in Covariance Structure Analysis: Conventional Criteria versus New Alternatives', Structural Equation Modeling, 6, 155. http://dx.doi.org/10.1080/10705519909540118

Jacobs, K., Petersen, L., Hörisch, J., and Battenfeld, D. (2018), 'Green thinking but thoughtless buying? An empirical extension of the value-attitude-behaviour hierarchy in sustainable clothing', Journal of Cleaner Production, 203, 1155-1169. https://doi.org/10.1016/j.jclepro.2018.07.320

Janssen, M., and Hamm, U. (2014), 'Governmental and private certification labels for organic food: Consumer attitudes and preferences in Germany', Food Policy, 49(P2), 437-448. https://doi.org/10.1016/j.foodpol.2014.05.011

Jöreskog, K. G., and Sörbom, D. (1981), LISREL V: Analysis of Linear Structural Relationships by Maximum Likelihood and Least Squares Methods. Chicago: National Educational Resources. Kokkinaki, F. (2009), 'Attitudinal and normative influence on behavioural intentions: the moderating role of meta-attitudinal judgments within the Theory of Reasoned Action', 
Psychology: The Journal of the Hellenic Psychological Society, 16(1), 28-43. https://doi.org/10.12681/psy_hps.23800

Ladhari, R., and Tchetgna, N. M. (2015), 'The influence of personal values on Fair Trade consumption', Journal of Cleaner Production, 87, 469-477. https://doi.org/10.1016/j.jclepro.2014.10.068.

Lafontaine, M. A., Nezakati, H., and Thwe, S. M. (2021), 'The Predictors of Organic Food Buying Behaviour: An Extension of Applied Norm Activation Model', Journal of Marketing Management and Consumer Behavior, 3(3), 41-58.

Liu, M. T., Liu, Y., and Mo, Z. (2020), 'Moral norm is the key: An extension of the theory of planned behaviour (TPB) on Chinese consumers' green purchase intention', Asia Pacific Journal of Marketing and Logistics, 32(8), 1823-1841. https://doi.org/10.1108/APJML-052019-0285

Marques Vieira, L., Dutra De Barcellos, M., Hoppe, A., and Bitencourt da Silva, S. (2013), 'An analysis of value in an organic food supply chain', British Food Journal, 115(10), 1454-1472. https://doi.org/10.1108/BFJ-06-2011-0160

Menozzi, D., Halawany-Darson, R., Mora, and C., Giraud, G. (2015), 'Motives towards traceable food choice: A comparison between French and Italian consumers', Food Control, 49, 40-48. https://doi.org/10.1016/j.foodcont.2013.09.006

McGuire, W. J. (1997), 'Creative hypothesis generating in psychology: Some useful heuristics', Annual Review of Psychology, 48 (1), 1-30. https://doi.org/10.1146/annurev.psych.48.1.1 MacKenzie, S.B., Podsakoff, P.M., and Podsakoff, N.P. (2011), ‘Construct Measurement and Validation Procedures in MIS and Behavioral Research: Integrating New and Existing Techniques', MIS Q., 35, 293-334. https://doi.org/10.2307/23044045 
Monier-Dilhan, S., and Bergès, F. (2016), 'Consumers' motivations driving organic demand: between self-interest and sustainability', Agricultural and Resource Economics Review, 45(3), 522-538. https://doi.org/10.1017/age.2016.6

Murphy, B., Benson, T., Lavelle, F., Elliott, C., and Dean, M. (2020), 'Assessing differences in levels of food trust between European countries', Food Control, 120, 107561. https://doi.org/10.1016/j.foodcont.2020.107561

Notani, A. S. (2008), 'Moderators of Perceived Behavioral Control's Predictiveness in the Theory of Planned Behavior: A Meta-Analysis', Journal of Consumer Psychology, 7(3), 247271. https://doi.org/10.1207/s15327663jcp0703_02

Nuttavuthisit, K., and Thøgersen, J. (2017), 'The Importance of Consumer Trust for the Emergence of a Market for Green Products: The Case of Organic Food', Journal of Business Ethics, 140(2), 323-337. https://doi.org/10.1007/s10551-015-2690-5

Olsen, N. V., Sijtsema, S. J., and Hall, G. (2010), ‘Predicting consumers’ intention to consume ready-to-eat meals. The role of moral attitude', Appetite, 55, 534-539. http://dx.doi.org/10.1016/j.appet.2010.08.016

Pawlewicz, A., Brodzinska, K., Zvirbule, A., and Popluga, D. (2020), 'Trends in the Development of Organic Farming in Poland and Latvia Compared to the EU', Rural Sustainability Research, 43(338), 1-8. https://doi.org/10.2478/plua-2020-0001

Perrini, F., Castaldo, S., Misani, N., and Tencati, A. (2010), 'The Impact of Corporate Social Responsibility Associations on Trust in Organic Products Marketed by Mainstream Retailers: A Study of Italian Consumers', Business Strategy and the Environment, 19(8), 512-526. https://doi.org/10.1002/bse.660 
Pieniak, Z., Aertsens, J., and Verbeke, W. (2010), 'Subjective and objective knowledge as determinants of organic vegetables consumption', Quality and Preference, 21, 581-588. https://doi.org/10.1016/j.foodqual.2010.03.004

Pivato, S., Misani, N., and Tencati, A. (2008), 'The impact of corporate social responsibility on consumer trust: the case of organic food', Business Ethics: A European Review, 17(1), 3-12. https://doi.org/10.1111/j.1467-8608.2008.00515.x

Radulescu, V., Cetina, I., Cruceru, A. F., and Goldbach, D. (2021), 'Consumers' Attitude and Intention towards Organic Fruits and Vegetables: Empirical Study on Romanian Consumers', Sustainability, 13, 9440. https://doi.org/ 10.3390/su13169440

Saba, A., and Messina, F. (2003), 'Attitudes towards organic foods and risk/benefit perception associated with pesticides', Food Quality and Preference, 14, 637-645. https://doi.org/10.1016/S0950-3293(02)00188-X

Saleki, R., Quoquab, F., and Mohammad, J. (2019), 'What drives Malaysian consumers' organic food purchase intention? The role of moral norm, self-identity, environmental concern and price consciousness', Journal of Agribusiness in Developing and Emerging Economies, 9(5), 584-603. https://doi.org/10.1108/JADEE-02-2019-0018

Scalco, A., Noventa, S., Sartori, S., and Ceschi, A. (2017), 'Predicting organic food consumption: A meta-analytic structural equation model based on the theory of planned behaviour', Appetite, 112, 235-248, http://dx.doi.org/10.1016/j.appet.2017.02.007

Smiglak-Krajewska, M., and Wojciechowska-Solis, J. (2021), 'Consumer versus Organic Products in the COVID-19 Pandemic: Opportunities and Barriers to Market Development', Energies, 14 (17), 5566. https://doi.org/10.3390/en14175566 
Spence, M., Stancu, V., Elliott, C. T., and Dean, M. (2018), 'Exploring consumer purchase intentions towards traceable minced beef and beef steak using the Theory of Planned Behaviour', Food Control, 91, 138-147. https://doi.org/10.1016/j.foodcont.2018.03.035 Steiger, J. H. (2007), 'Understanding the limit actions of global fit assessment in structural equation modelling', Personality and Individual Differences, 42(5), 893-898. https://doi.org/10.1016/j.paid.2006.09.017

Sultan, P., Tarafder, T., Pearsonc, D., and Henryks, J. (2020), 'Intention-behaviour gap and perceived behavioural control-behaviour gap in theory of planned behaviour: moderating roles of communication, satisfaction and trust in organic food consumption', Food Quality and Preference, 81, 103838. https://doi.org/10.1016/j.foodqual.2019.103838

Teng, C. C. and Lu, C. H. (2016), 'The relationship between involvement and purchase intention for organic food becomes weaker in the condition of consumers with higher degree of uncertainty', Appetite, 105, 95-105. https://doi.org/10.1016/j.appet.2016.05.006

Thøgersen, J. (2009), Consumer decision-making with regard to organic food products'. In M. T. de Noronha-Vaz, P. Nijkamp, and J. L. Rastoin (Eds.), Traditional food production facing sustainability: A European challenge (pp. 173-194). Farnham: Ashgate.

van Rijswijk, W., and Frewer, L. J. (2008), 'Consumer perceptions of food quality and safety and their relation to traceability', British Food Journal, 110(10), 1034-1046.

Yadav, R., and Pathak, G. S. (2016), 'Young consumers' intention towards buying green products in a developing nation: Extending the theory of planned behavior', Journal of Cleaner Production, 135, 732-739. https://doi.org/10.1016/j.jclepro.2016.06.120

Willer, H., Schaack, D. and Lernoud, J. (2019), ‘Organic Farming and Market Development in Europe and the European Union'. In: Willer, H. and Lernoud, J. (Eds.) The World of Organic 
Agriculture. Statistics and Emerging Trends 2019. Research Institute of Organic Agriculture FiBL and IFOAM - Organics International, Frick and Bonn, pp. 217-254.

Willer, H. (2020), 'Organic market worldwide: observed trends in the last few years. Bio Eco Actual digital edition'. Online at https://www.bioecoactual.com/en/2020/03/10/organicmarket-worldwide-observed-trends-in-the-last-few-years/, accessed on: 17 December 2021. 


\section{Figure Captions}

FIGURE 1. Development of the organic vegetables purchase intention: theoretical SEM.

LEGEND: Pint = Purchase intention; $\mathrm{PeBC}=$ Perceived behavioural control; Att $=$ Attitude $;$ PoMA = Positive moral attitude; Bel = Beliefs; SbN = Subjective norms; PeSN = Perceived social norms; Past = Past behaviour; ObK = Objective knowledge; SbK = Subjective knowledge; Unc = Uncertainty; OrgT = Organizational trust; ProT = Product trust; IntT = Interpersonal trust; $\mathrm{ChT}=$ Chain trust.

FIGURE 2. SEM model, standardized estimates.

LEGEND: Pint $=$ Purchase intention; $\mathrm{PeBC}=$ Perceived behavioural control; $A$ At $=$ Attitude PoMA $=$ Positive moral attitude; Bel = Beliefs; SbN = Subjective norms; PeSN = Perceived social norms; Past = Past behaviour; ObK = Objective knowledge; $\mathrm{SbK}=$ Subjective knowledge; Unc = Uncertainty; OrgT = Organizational trust; ProT = Product trust; IntT = Interpersonal trust; $\mathrm{ChT}=$ Chain trust. 


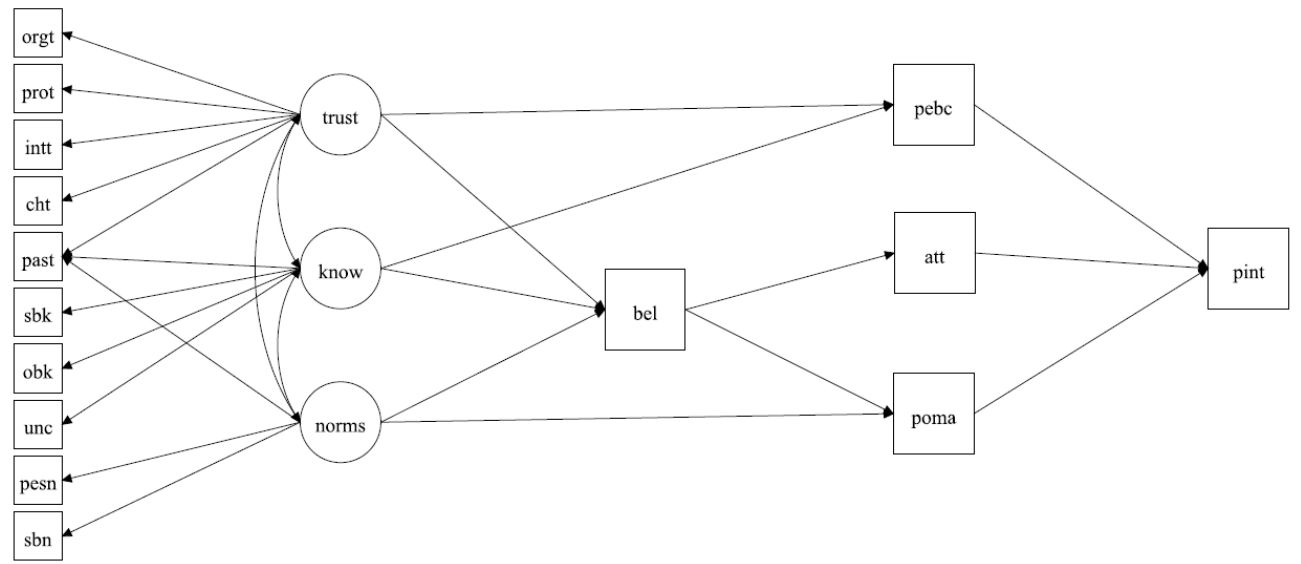

FIGURE 1. Development of the organic vegetables purchase intention: theoretical SEM $830 \times 479 \mathrm{~mm}(38 \times 38 \mathrm{DPI})$ 
Table 1. Respondents' socio-demographic characteristics

\begin{tabular}{|c|c|c|}
\hline Sample & & $N=1035$ \\
\hline \multirow[t]{2}{*}{ Gender } & Female & $52.5 \%$ \\
\hline & Male & $47.5 \%$ \\
\hline \multirow[t]{6}{*}{ Age } & $18-24$ & $9.2 \%$ \\
\hline & $25-34$ & $18.1 \%$ \\
\hline & $35-44$ & $17.4 \%$ \\
\hline & $45-54$ & $16.6 \%$ \\
\hline & $55-64$ & $15.5 \%$ \\
\hline & $\geq 65$ & $23.3 \%$ \\
\hline \multirow[t]{4}{*}{ Country } & $U K$ & $24.5 \%$ \\
\hline & Germany & $24.9 \%$ \\
\hline & Italy & $24.9 \%$ \\
\hline & Poland & $25.6 \%$ \\
\hline \multirow[t]{5}{*}{ Marital status } & Married or Living with partner & $74.5 \%$ \\
\hline & Single (never married) & $15.5 \%$ \\
\hline & Widowed & $3.1 \%$ \\
\hline & Divorced or Separated & $6.5 \%$ \\
\hline & Prefer not to answer & $.5 \%$ \\
\hline \multirow[t]{4}{*}{ Children under 16} & 0 & $60.2 \%$ \\
\hline & 1 & $20.4 \%$ \\
\hline & 2 & $15.0 \%$ \\
\hline & $\geq 3$ & $4.4 \%$ \\
\hline \multirow[t]{7}{*}{ Occupation status } & Full time paid work (30+ hours per week) & $57.2 \%$ \\
\hline & Part-time paid work & $10.3 \%$ \\
\hline & Retired & $22.6 \%$ \\
\hline & At school & $1.0 \%$ \\
\hline & In full-time higher education & $3.1 \%$ \\
\hline & Unemployed (seeking work) & $9.3 \%$ \\
\hline & Full-time homemaker & $3.8 \%$ \\
\hline Organic purchase & Rarely & $7.8 \%$ \\
\hline \multirow[t]{2}{*}{ frequency } & Sometimes & $24.9 \%$ \\
\hline & Very often & $67.2 \%$ \\
\hline
\end{tabular}


Table 2. Constructs and items: examples, number and response scale of the items included in the survey instrument

\begin{tabular}{|c|c|c|c|c|c|}
\hline \multicolumn{2}{|c|}{ Section } & \multirow{2}{*}{$\begin{array}{c}\text { Construct } \\
\text { Perceived social norms }\end{array}$} & \multirow{2}{*}{$\begin{array}{l}\text { Example item } \\
\text { "I would buy organic vegetables because... The media } \\
\text { (TV, radio) are in favour of it" }\end{array}$} & \multirow{2}{*}{$\begin{array}{c}\begin{array}{c}\mathrm{N} \text { of } \\
\text { items }\end{array} \\
3\end{array}$} & \multirow{2}{*}{\begin{tabular}{l}
\multicolumn{1}{c}{ Response scale } \\
Likert-type: \\
1-strongly disagree to \\
7- strongly agree
\end{tabular}} \\
\hline $\begin{array}{l}T \\
R \\
A\end{array}$ & $\begin{array}{l}\text { Theory of Planned } \\
\text { Behaviour variables }\end{array}$ & & & & \\
\hline $\begin{array}{l}\text { D } \\
1 \\
T\end{array}$ & & Subjective norms & $\begin{array}{l}\text { "I would buy organic vegetables because... My family, } \\
\text { partner and friends approve" }\end{array}$ & 2 & $\begin{array}{l}\text { Likert-type: } \\
\text { 1-strongly disagree to } \\
\text { 7- strongly agree }\end{array}$ \\
\hline $\begin{array}{l}1 \\
\mathrm{O} \\
\mathrm{N}\end{array}$ & & $\begin{array}{l}\text { Perceived behavioural } \\
\text { control }\end{array}$ & $\begin{array}{l}\text { "If I wanted to, it would be possible for me to buy } \\
\text { organic vegetables instead of conventional" }\end{array}$ & 3 & $\begin{array}{l}\text { Likert-type: } \\
\text { 1-strongly disagree to } \\
\text { 7- strongly agree }\end{array}$ \\
\hline $\begin{array}{l}\text { A } \\
\text { L }\end{array}$ & & Behavioural beliefs & $\begin{array}{l}\text { "Buying organic vegetables instead of conventional } \\
\text { vegetables would be... free from chemicals such as } \\
\text { additives or residues from fertilizers, pesticides or } \\
\text { herbicides" }\end{array}$ & 8 & $\begin{array}{l}\text { Likert-type: } \\
\text { 1-strongly disagree to } \\
\text { 7- strongly agree }\end{array}$ \\
\hline $\begin{array}{l}\mathrm{P} \\
\mathrm{B}\end{array}$ & & Intention to buy & $\begin{array}{l}\text { "I intend to buy organic fresh tomatoes instead of } \\
\text { conventional ones in the near future" }\end{array}$ & 2 & $\begin{array}{l}\text { Likert-type: } \\
\text { 1-strongly disagree to } \\
\text { 7- strongly agree }\end{array}$ \\
\hline $\begin{array}{l}M \\
O \\
D \\
E \\
L\end{array}$ & & Attitude & $\begin{array}{l}\text { "Buying organic vegetables instead of conventional } \\
\text { vegetables now available in supermarkets would make } \\
\text { me feel" }\end{array}$ & 6 & $\begin{array}{l}\text { Semantic-differential } \\
\text { scale: } \\
\text { 1- bad to 7-good }\end{array}$ \\
\hline & Habit strength & Past behaviour & $\begin{array}{l}\text { "How often have you purchased organic food such as } \\
\text { organic food for your household?" }\end{array}$ & 1 & $\begin{array}{l}\text { Likert-type: } \\
\text { 1- Every day or almost } \\
\text { every day to 8- Once/ } \\
\text { Twice per year }\end{array}$ \\
\hline $\begin{array}{l}X \\
T \\
E\end{array}$ & $\begin{array}{l}\text { Knowledge of the } \\
\text { organic }\end{array}$ & Objective knowledge & $\begin{array}{l}\text { "Please indicate, based on your opinion, if the following } \\
\text { statements are true or false: Organic farmers do not } \\
\text { use synthetic pesticides" }\end{array}$ & 4 & $\begin{array}{l}\text { Likert-type: } \\
\text { 1-strongly disagree to } \\
\text { 7- strongly agree }\end{array}$ \\
\hline $\begin{array}{l}N \\
S\end{array}$ & & Subjective knowledge & $\begin{array}{l}\text { "Compared to most other people, I know less about } \\
\text { organic food" }\end{array}$ & 5 & Likert-type: \\
\hline
\end{tabular}




\begin{tabular}{|c|c|c|c|c|c|}
\hline $\begin{array}{l}1 \\
0\end{array}$ & & & & & $\begin{array}{l}\text { 1-strongly disagree to } \\
\text { 7- strongly agree }\end{array}$ \\
\hline $\begin{array}{l}\mathrm{O} \\
\mathrm{F}\end{array}$ & & $\begin{array}{l}\text { Uncertainty and } \\
\text { confidence in organic } \\
\text { vegetables knowledge } \\
\text { and product } \\
\text { information }\end{array}$ & "I'm not sure of my knowledge about organic foods" & 6 & $\begin{array}{l}\text { Likert-type: } \\
\text { 1-strongly disagree to } \\
\text { 7- strongly agree }\end{array}$ \\
\hline $\begin{array}{l}\mathrm{T} \\
\mathrm{H}\end{array}$ & $\begin{array}{l}\text { Positive moral } \\
\text { attitude }\end{array}$ & Positive moral attitude & $\begin{array}{l}\text { "Buying organic vegetables instead of conventional } \\
\text { vegetables would ... make me feel like a better person". }\end{array}$ & 3 & $\begin{array}{l}\text { Likert-type: } \\
\text { 1-strongly disagree to } \\
\text { 7- strongly agree }\end{array}$ \\
\hline $\begin{array}{l}\mathrm{E} \\
\mathrm{T}\end{array}$ & $\begin{array}{l}\text { Consumer Trust in } \\
\text { organic food }\end{array}$ & Interpersonal trust & 'Most people are basically honest' & 4 & $\begin{array}{l}\text { Likert-type: } \\
\text { 1-strongly disagree to } \\
\text { 7- strongly agree }\end{array}$ \\
\hline $\begin{array}{l}P \\
B\end{array}$ & & Organizational trust & $\begin{array}{l}\text { 'European Food Safety Authority (EFSA) has practices } \\
\text { that favor the consumer's best interests' }\end{array}$ & 17 & $\begin{array}{l}\text { Likert-type: } \\
\text { 1-strongly disagree to } \\
\text { 7- strongly agree }\end{array}$ \\
\hline $\begin{array}{l}M \\
\mathrm{O} \\
\mathrm{D}\end{array}$ & & Food chain trust & $\begin{array}{l}\text { "(National organic certification body) are honest about } \\
\text { the safety of food" }\end{array}$ & 7 & $\begin{array}{l}\text { Likert-type: } \\
\text { 1-strongly disagree to } \\
\text { 7- strongly agree }\end{array}$ \\
\hline $\begin{array}{l}\mathrm{E} \\
\mathrm{L}\end{array}$ & & Product trust & 'I trust that organic vegetables' are authentic' & 10 & $\begin{array}{l}\text { Likert-type: } \\
\text { 1-strongly disagree to } \\
\text { 7- strongly agree }\end{array}$ \\
\hline
\end{tabular}


Table 3. Scales reliability (AVE, CR and Cronbach's alpha on the principal diagonal), Scores description (M, SD) and bivariate correlations

\begin{tabular}{|c|c|c|c|c|c|c|c|c|c|c|c|c|c|c|c|}
\hline & 1. & 2. & 3. & 4. & 5. & 6. & 7. & 8. & 9. & 10. & 11. & 12. & 13. & 14. & 15. \\
\hline 1.Pint & .938 & & & & & & & & & & & & & & \\
\hline 2.PeBC & $.270^{* *}$ & .648 & & & & & & & & & & & & & \\
\hline 3.Att & $.600 * *$ & $.269 * *$ & .915 & & & & & & & & & & & & \\
\hline 4.PoMA & $.691 * *$ & $.141^{* *}$ & $.640 * *$ & .914 & & & & & & & & & & & \\
\hline 5.Bel & $.622 * *$ & $.159 * *$ & $.620 * *$ & $.733^{* *}$ & .873 & & & & & & & & & & \\
\hline 6.SbN & $.584^{* *}$ & $.137^{* *}$ & $.528^{* *}$ & $.609 * *$ & $.515^{* *}$ & .895 & & & & & & & & & \\
\hline 7.PeSN & $.557^{* *}$ & $.098^{*}$ & $.518^{* *}$ & $.623 * *$ & $.516^{* *}$ & $.908 * *$ & .864 & & & & & & & & \\
\hline 8.Past ${ }^{\S}$ & $.449 * *$ & $.085^{*}$ & $.233^{* *}$ & $.302 * *$ & $.218^{* *}$ & $.383 * *$ & $.391^{* *}$ & - & & & & & & & \\
\hline $9.0 \mathrm{bK}$ & $.199 * *$ & $.137 * *$ & $.255^{* *}$ & $.207^{* *}$ & $.239 * *$ & $.135^{* *}$ & $.078^{*}$ & -.006 & .607 & & & & & & \\
\hline 10.SbK & $.327^{* *}$ & $.294^{* *}$ & $.308^{* *}$ & $.227^{* *}$ & $.222 * *$ & $.182^{* *}$ & $.163^{* *}$ & $.270^{* *}$ & $.182^{* *}$ & .748 & & & & & \\
\hline 11.Unc & $-.151^{* *}$ & $-.305^{* *}$ & $-.208^{* *}$ & $-.145^{* *}$ & $-.137^{* *}$ & $-.063^{*}$ & -.034 & .002 & $-.207^{* *}$ & $-.573 * *$ & .910 & & & & \\
\hline 12.OrgT & $.485^{* *}$ & $.164^{* *}$ & $.475^{* *}$ & $.590 * *$ & $.528^{* *}$ & $.485^{* *}$ & $.546 * *$ & $.224 * *$ & $.142^{* *}$ & $.225^{* *}$ & $-.143^{* *}$ & .986 & & & \\
\hline 13.ProT & $.374^{* *}$ & $.157^{* *}$ & $.338^{* *}$ & $.459 * *$ & $.378^{* *}$ & $.406 * *$ & $.472^{* *}$ & $.251^{* *}$ & $.062^{*}$ & $.164 * *$ & $-.071^{*}$ & $.712^{* *}$ & .977 & & \\
\hline 14.IntT & $.301 * *$ & $.110 * *$ & $.255^{* *}$ & $.343 * *$ & $.284^{* *}$ & $.383 * *$ & $.424^{* *}$ & $.196 * *$ & -.028 & $.103^{*}$ & .021 & $.562^{* *}$ & $.568^{* *}$ & .930 & \\
\hline 15.ChT & $.300 * *$ & $.195^{* *}$ & $.296 * *$ & $.380 * *$ & $.355^{* *}$ & $.385^{* *}$ & $.428^{* *}$ & $.137^{* *}$ & .008 & $.091^{*}$ & -.025 & $.636^{* *}$ & $.595^{* *}$ & $.645^{* *}$ & .952 \\
\hline AVE & .943 & .594 & .703 & .854 & .567 & .824 & .787 & - & .605 & .612 & .690 & .814 & .830 & .827 & .777 \\
\hline CR & .971 & .814 & .934 & .946 & .906 & .904 & .917 & - & .821 & .858 & .930 & .987 & .980 & .950 & .961 \\
\hline$M$ & 5.27 & 4.71 & 5.43 & 5.01 & 5.29 & 4.67 & 4.51 & 5.86 & 2.94 & 4.24 & 3.83 & 4.77 & 4.59 & 4.40 & 4.71 \\
\hline SD & 1.41 & 1.18 & 1.25 & 1.42 & 1.05 & 1.56 & 1.44 & 1.76 & 1.18 & 1.16 & 1.38 & 1.30 & 1.37 & 1.34 & 1.21 \\
\hline
\end{tabular}

LEGEND: Pint = Purchase intention; PeBC = Perceived behavioural control; Att = Attitude; PoMA = Positive moral attitude; Bel = Beliefs; SbN = Subjective norms; PeSN = Perceived social norms; Past = Past behaviour; ObK = Objective knowledge; $\mathrm{SbK}=$ Subjective knowledge; Unc = Uncertainty; OrgT = Organizational trust; ProT $=$ Product trust; Int $\mathrm{O}=$ Interpersonal trust; $\mathrm{ChT}=$ Chain trust

$\S=$ single item

${ }^{* *} p<.001 ; * p<.05$ 


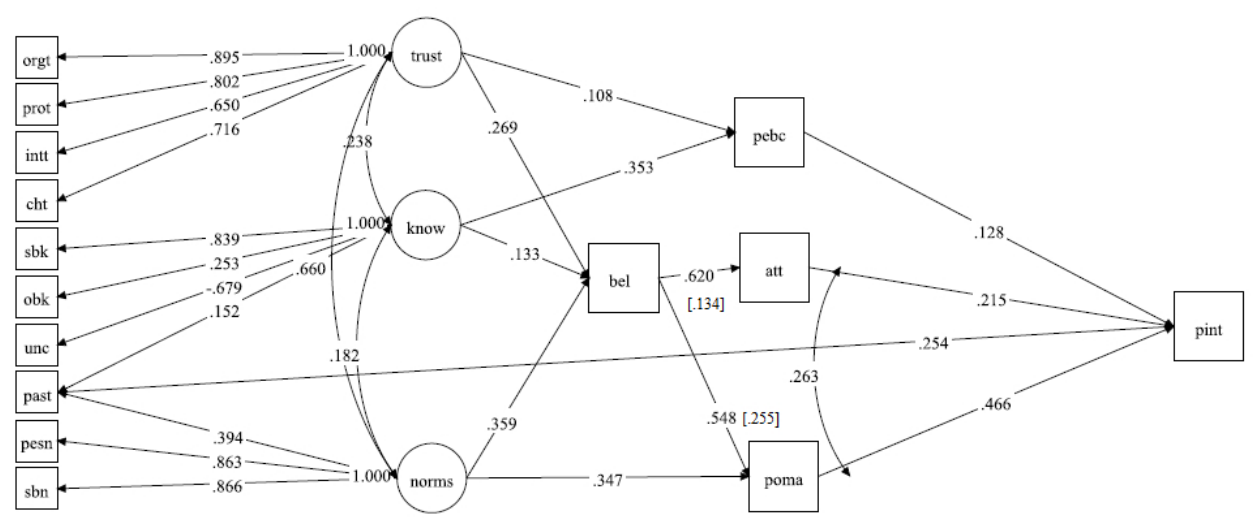

FIGURE 2. SEM model, standardized estimates

$667 \times 270 \mathrm{~mm}(38 \times 38 \mathrm{DPI})$ 